\title{
Fatal and serious complications associated with cosmetic suction lipectomy
}

\author{
S Lori Brown PhD MPH${ }^{1}$, Janos T Bacsanyi MD ${ }^{2}$, Sherry L Purvis-Wynn BSN MA ${ }^{1}$
}

\begin{abstract}
SL Brown, JT Bacsanyi, SL Purvis-Wynn. Fatal and serious complications associated with cosmetic suction lipectomy. Can J Plast Surg 2002;10(2):69-74.
\end{abstract}

Liposuction is the most commonly performed cosmetic surgery procedure in the United States. The medical devices and drugs used in the performance of liposuction are regulated by the Food and Drug Administration. Serious liposuction-related complications, including death, are reported in the literature. A review of reported complications and causes of deaths related to liposuction is presented. Prospective studies examining potential risk factors for complications, such as amount of fatty tissue removed and extent of body surface area affected, concomitant surgeries, method of anesthesia, impact of physician training and site of surgery, are needed to clarify the risks involved in liposuction. Studies are required to establish the risk-benefit profile of this procedure to allow patients and physicians to be adequately informed. Adverse events have been under-reported to the Food and Drug Administration despite numerous reports in the medical literature of serious complications associated with the use of medical devices in the performance of liposuction.

\section{Complications graves, voire mortelles, associées à la liposuccion esthétique}

RÉSUMÉ : La liposuccion est la forme la plus courante de chirurgie esthétique aux États-Unis. Les dispositifs médicaux et les médicaments utilisés à cette fin sont régis par la Food and Drug Administration. La documentation scientifique fait état de complications graves, voire mortelles, liées à la liposuccion. Le présent article passe en revue les complications déclarées et les causes de mortalité associées à l'intervention. Des études prospectives portent sur les facteurs de risque possibles de complication, comme la quantité de tissu adipeux prélevé et l'étendue de la surface corporelle touchée, les interventions chirurgicales concomitantes, le type d'anesthésie, la formation des médecins et l'établissement où est pratiquée l'intervention. Il faut mener des études pour établir le rapport risquesavantages de la liposuccion afin de permettre aux patients et aux médecins de prendre des décisions éclairées. Il y a sous-notification des effets indésirables à la Food and Drug Administration malgré le fait que la documentation rapporte de nombreuses complications graves associées à l'utilisation de dispositifs médicaux au cours de la liposuccion.

Key Words: Complications; Lipectomy; Liposuction; Mortality

L iposuction (suction lipectomy or lipoplasty) is a surgical technique for removing fat deposits. Localized subcutaneous fat deposits are removed using a vacuum suction cannula in traditional suction-assisted liposuction (SAL). An ultrasonic surgical aspirator is used in ultrasound-assist- ed liposuction (UAL). In both cases, the goal is to attain an improved body contour by removal of unwanted fat deposits. While some physicians stress patient selection, and use liposuction as an adjunct to diet and exercise $(1,2)$, reports of aspirating multiple litres of fatty tissue from mul-

${ }^{1}$ Office of Surveillance and Biometrics, Center for Devices and Radiological Health and ${ }^{2}$ Office of Post-Marketing Drug Risk Assessment, Center for Drug Evaluation and Research, United States Food and Drug Administration, Rockville, Maryland, USA

Correspondence: Dr S Lori Brown, 1350 Piccard Drive, HFZ-541, Rockville, Maryland 20850, USA. Telephone 301-594-0610, fax 301-594-0050, e-mail syb@cdrh.fda.gov 
tiple anatomical sites suggest that it is also being used for weight reduction. This procedure has been used to remove fat from the abdomen, buttocks, back, waist, thighs, knees, legs, calves, ankles, arms, breast, neck and face. Liposuction is the most commonly performed aesthetic surgical procedure in the United States, with the American Society of Plastic Surgeons reporting 230,865 procedures performed by physicians certified by the American Board of Plastic Surgeons in 1999 (3). This represents a 389\% increase in the performance of this procedure between 1992 and 1999. An estimate of the performance of this technique by any practitioner was 293,000 procedures in 1996 (4). Suction lipectomy may be performed in physicians' offices, ambulatory surgical centres or hospital operating rooms. Serious complications and fatalities have occurred in association with this procedure. There is a growing concern that serious or fatal liposuction outcomes are under-reported (4-6). Given the predominant use of liposuction for cosmetic purposes and its growing frequen$\mathrm{cy}$, this is of great concern to physicians, patients, manufacturers and regulators.

\section{LIPOSUCTION TECHNIQUES}

Liposuction can be broken down into two categories: traditional SAL and UAL. Liposuction may be performed using the dry technique, the wet technique, or the tumescent or superwet technique. Dry liposuction is performed under general anesthesia without infiltration and with high vacuum suction (7). The cannula is inserted into incisions at the target area to suction fat cells from the area. The dry technique reportedly may result in substantial fluid loss, ecchymosis, hematoma and infection, and is used less commonly (8). The wet technique uses a small infused volume of solution, between 100 to $300 \mathrm{~mL}$, regardless of the amount of fat to be removed. In contrast, in the superwet or tumescent technique, the patient is infused with large volumes of fluid preoperatively until the skin is turgid, using as much as $3 \mathrm{~mL}$ of infusate for each $1 \mathrm{~mL}$ to be removed (9). The infiltration fluid typically has adrenaline added to reduce bleeding through vasoconstriction. Dilute lidocaine is used as anesthesia, either in the infiltration solution alone, or in conjunction with intramuscular or intravenous sedation, spinal anesthesia or general anesthesia.

UAL is generally used with tumescent infiltration, and differs from standard liposuction in that ultrasound energy is applied to and transmitted through the liposuction cannula to the tissue. As in standard liposuction, a vacuum is applied to the cannula to aspirate disrupted tissue and instillate. Some ultrasound cannulas are supplied with outer sheaths and an option for operative field irrigation through the sheath. Solid cannulas, referred to as probes, do not provide a venue for aspiration. Ultrasound energy, as applied to the lipoplasty cannula and probes, is thought to work by some combination of three basic mechanisms $(10,11)$ : first, cavitation or the generation and collapse of gas bubbles in tissue, with the ensuing fragmentation of cells; second, mechanical forces associated with the cannu- la vibrations, which break or fragment cells; and third, thermal effects. The long term tissue effects of ultrasound energy at the levels of energy that are applied in lipoplasty are not known.

\section{LIPOSUCTION EQUIPMENT AND DRUG REGULATION BY THE UNITED STATES FOOD AND DRUG ADMINISTRATION}

The United States Food and Drug Administration (FDA) regulates the medical devices and drugs used in liposuction. The devices include various mechanical pumps, electricpowered aspirators, collection devices, cannulas and ultrasound generators and probes $(12,13)$. Many devices marketed in the United States and used in the performance of SAL and UAL are devices that were on the market before the 1976 Medical Device Amendments (14), and are legally labelled with an indication for use in 'soft tissue aspiration'. These preamendment devices are not labelled specifically for lipoplasty. Devices for SAL that are specifically indicated for 'aesthetic body contouring' were classified as class III devices in 1983, because there was insufficient information to support the safety and effectiveness of soft tissue aspiration devices for the intended use of suction lipoplasty. Subsequently, sufficient literature information was provided to the FDA to allow the FDA to evaluate the safety and effectiveness of suction-assisted soft tissue aspiration devices with the specific indication for use of 'aesthetic body contouring' and to reclassify these devices as class II in 1998. As class II devices, suction-assisted soft tissue aspiration devices with the specific indication for use of aesthetic body contouring require special regulatory controls to be met for device clearance for marketing. In this case, the special controls include consensus standards and labelling restrictions.

Currently, six companies have clearance to market their suction lipoplasty systems for aesthetic body contouring. One American company now has clearance to market ultrasound probes or ultrasound-assisted suction devices for this indication for use. A "Points to Consider" letter issued by the FDA in 1996 detailed important issues to be considered in the design of clinical studies that evaluate the safety and effectiveness of UAL devices. Issues highlighted in the "Points to Consider" letter included: the volume of soft tissue aspirate; body surface area subjected to injection and aspiration; volume of subcutaneous fluid injection, and associated doses of components such as lidocaine and epinephrine; comorbidities that may decrease a patient's ability to tolerate the procedure; and predictability of outcomes. In addition, an issue specific to ultrasound-assisted suction devices used for lipoplasty is thermal effects due to ultrasound energy (ie, burns at the cannula entry site and at the subcutaneous level of cannula use). An objective clinical study of ultrasound-assisted device use in lipoplasty is necessary to address these issues.

Drugs used during liposuction are also regulated by the FDA. Of special concern is the dose of lidocaine administered in lipoplasty procedures. The concentration of lido- 
caine infusate varies from $0.25 \%$ to $0.5 \%$ in the literature. While the concentration is low, the lidocaine dose may range from 20 to $80 \mathrm{mg} / \mathrm{kg}$ or higher because of the large volumes infused for the tumescent technique. This far exceeds the recommended, labelled safe dose and is considered an off-label use of lidocaine. To date, no data have been presented to the FDA to support the safety and efficacy of these doses and techniques of lidocaine administration. Lidocaine labelling explicitly states:

For normal healthy adults, the individual maximum recommended dose of lidocaine $\mathrm{HCl}$ with epinephrine should not exceed $7 \mathrm{mg} / \mathrm{kg}(3.5 \mathrm{mg} / \mathrm{lb})$ of body weight, and in general, it is recommended that the maximum total dose not exceed $500 \mathrm{mg}$. When used without epinephrine, the maximum individual dose should not exceed $4.5 \mathrm{mg} / \mathrm{kg}(2 \mathrm{mg} / \mathrm{lb})$ of body weight, and in general, it is recommended that the maximum total dose does not exceed $300 \mathrm{mg}$. (15)

\section{SERIOUS MORBIDITY AND MORTALITY RELATED TO LIPOSUCTION}

Serious complications, including death, have been reported after liposuction procedures. A list of reported complications is shown in Table 1.

A computer search was performed of all deaths referred to the Office of the Chief Medical Examiner of the City of New York during the period from 1993 to 1996. Five of the deaths were classified as related to liposuction (7). Four of these liposuction procedures were performed by plastic surgeons, and one was performed by a general surgeon. One patient died of fluid overload, and a second patient died of deep venous thrombosis of the calf veins with pulmonary thromboembolism. Three of the patients died intraoperatively after developing hypotension and bradycardia, leading the authors to speculate that lidocaine toxicity may have played a role in these deaths. The dose of lidocaine advocated for use in tumescent liposuction is between 10 and $88 \mathrm{mg} / \mathrm{kg}$ (7,16-18). A recent research report, based on a small number of subjects, indicated that adrenaline may delay lidocaine absorption, potentially extending the period over which lidocaine is removed (19). These authors speculated that the gradual increase in plasma levels of lidocaine may induce tolerance to higher plasma levels of lidocaine.

Some advocates of the tumescent technique oppose the concomitant use of other methods of anesthesia (20-22), while others use intramuscular (23) or intravenous sedation, short-acting spinal anesthesia or general anesthesia $(9,24)$. Systemic and localized adverse effects of lidocaine may occur because of excessive dose, rapid absorption or inadvertent intravascular injection, resulting in toxic blood levels. Lidocaine is known to cause concentration-dependent central nervous system (CNS) toxicity, characterized by excitation and seizures or, in some cases, CNS depression with drowsiness, respiratory failure and coma. CNS depression may be the first manifestation of CNS toxicity in some
TABLE 1

Reported complications associated with liposuction

\begin{tabular}{|c|c|}
\hline Complication & Reference \\
\hline Anemia & 22 \\
\hline Burns (ultrasound-assisted liposuction) & 38,48 \\
\hline $\begin{array}{l}\text { Cardiac arrhythmia, bradycardia, myocardial } \\
\text { infarction }\end{array}$ & $5,49,50$ \\
\hline Cerebrovascular accident & 50 \\
\hline Deep vein thrombosis & $6,38,50,51$ \\
\hline Dysesthesia & $38,48,52,53$ \\
\hline Edema & 49 \\
\hline Fat embolism & $4,6,25-30,37,50$ \\
\hline Hearing loss, acute & 54 \\
\hline Hemorrhage & 4 \\
\hline Hypovolemia & $5,6,38$ \\
\hline Infectious cellulitis & 35,51 \\
\hline Infection & $4,36,38,49,52,53$ \\
\hline Lidocaine toxicity or anesthesia complication & $4,6,20,24,38,50$ \\
\hline Necrosis, skin or tissue & $22,38,51$ \\
\hline Necrotizing fasciitis & 31,32 \\
\hline Nerve compression & 55 \\
\hline Nerve damage (ultrasound-assisted liposuction) & 40 \\
\hline Persistent pain & $49,50,53$ \\
\hline Postoperative pneumonia & 51 \\
\hline Pulmonary embolism & $6,50,51$ \\
\hline Pulmonary edema & 24,38 \\
\hline Renal failure, acute & 8,56 \\
\hline Seroma & $38,48,49,51-53$ \\
\hline Thromboembolism & 5,6 \\
\hline Toxic shock syndrome & 33,34 \\
\hline $\begin{array}{l}\text { Visceral perforation (thoracic, abdominal, } \\
\text { aortic, etc) }\end{array}$ & $4,37,38,50,57$ \\
\hline
\end{tabular}

patients. Cardiovascular toxicity generally begins after signs of CNS toxicity have occurred. Higher plasma concentrations of lidocaine impair myocardial contractility and decrease conduction velocity in the heart, which may progress to sinus bradycardia, arrhythmias or asystole. Lidocaine toxicity may also develop as a result of interactions with other drugs (20).

Deaths due to fat emboli have been reported in several case reports. One such report described a healthy 56-year-old man undergoing abdominoplasty and lipectomy (25). In the emergency room, a lung scan and pulmonary arteriogram were suggestive of bilateral pulmonary emboli. During an autopsy, emboli were found in the heart, lungs and brain. The author of this case report speculated on the risk of complications in cases in which liposuction is performed in conjunction with other surgery. Morbidity in SAL combined with other procedures exceeding $6 \mathrm{~h}$ has been reported by others to be a risk factor for complications 
(26). Other reported cases of fat embolism have occurred in patients undergoing multiple procedures (27-30), causing some people to speculate that it was not the liposuction procedure alone that was causing the fat embolism. Despite uncertainty over the role of concurrent surgeries (which have included mastopexy, mammoplasty and abdominoplasty), liposuction is the common procedure and a plausible explanation for the development of fat embolism or fat embolism syndrome.

Infection is another potential cause of death postlipectomy $(31,32)$. One case report described a 36-year-old woman who complained of fever, chills and severe pain in her arms, thighs and knees within hours after surgery (31). Fortyeight hours after surgery, the patient reported to the emergency room. She ultimately died of necrotizing fasciitis despite antibiotics, hyperbaric oxygen and extensive surgical debridement of the necrotic tissue.

Toxic shock syndrome has also been reported after suction lipectomy $(33,34)$. In one case, toxic shock syndrome was accompanied by necrotizing fasciitis typified by extensive skin necrosis (33). In this case, a formerly healthy young woman was referred to the emergency room by the cosmetic surgery hospital two days postoperatively. She had undergone lipectomy of the abdomen, buttocks and thighs in an office procedure by a cosmetic surgeon. Staphylococcus aureus was grown from intraoperative cultures. The patient ultimately had open wounds covering $22 \%$ of her body and required extensive autografts. After months of hospitalization and intensive medical treatment, the patient was released. Severe infectious cellulitis characterized by high fever, painful induration, inflammation, necrosis and sepsis has also been reported (35). A cluster of rapidly growing mycobacterial infections after liposuction emphasizes the importance of cleaning and sterilizing (reprocessing) liposuction equipment between patients to prevent nosocomial infections (36).

Another source of morbidity or mortality arises from visceral perforations. Intestinal perforation after liposuction has been reported to occur, with a mortality rate of greater than 50\% (37). In one recent case report, a 50-year-old patient, having undergone abdominal liposuction, complained of nausea, vomiting and abdominal pain within $24 \mathrm{~h}$ of the surgery (37). By the third postoperative day, she had developed fever and chills, and was referred to the emergency room. Six enterotomies were observed in a $1.5 \mathrm{~m}$ segment of the small bowel and required resection. After a complicated postoperative course, the patient was discharged on day 25. Others have reviewed the literature for incidents of visceral perforation and have reported nine cases of intestinal perforations (38).

\section{SOME SPECIAL PROBLEMS WITH UAL}

The mechanism of action of UAL is not completely understood. Because heat may destroy tissues and cavitation may produce oxygen free radicals, some people have expressed concerns over the widespread use of this technique (39). Potential nerve damage due to preferential emulsification of adipose tissue, such as that contained within the myelin sheath, may place peripheral nerves at high risk to ultrasound injury. Injury to blood vessels and peripheral nerves by UAL are potentially serious problems, and visible nerve damage without evident functional damage has been observed in experimental animals exposed to low amplitude ultrasonic energy (40). Dysesthesias have been reported to be a complication of UAL (38).

\section{MORTALITY ASSESSED IN SURVEYS OR SELF-REPORTED SERIES}

A search of the Internet yielded descriptions of 39 deaths related to liposuction. The majority of these deaths were reported in news reports or features. Causes of death included infection, respiratory arrest, heart attack, anesthesia overdose and pulmonary emboli. Over one-half of the decedents (21 of 39) were reported to be female and three of 39 were male; the genders of the remaining 15 of 39 were unspecified.

Published literature on the causes of liposuction-related mortality has provided few answers and has highlighted an ongoing controversy between practitioners from different specialties $(22,41,42)$. Many issues, such as physician's training, board certification, volume of fat removed during a single procedure, impact of ancillary or concurrent procedures, length of surgery, type of anesthesia $(43,44)$ and safety of office versus surgical centre versus hospital procedures (42), have not been studied adequately, but may potentially impact liposuction outcomes. Most of the studies performed to date were retrospective medical record reviews of single practices or voluntary surveys of selected professional societies' memberships and have not unambiguously addressed these issues.

Several surveys have estimated the death rate from liposuction (Table 2). It should be noted that all of these surveys are aimed at members of a particular professional association and are voluntary, and the response rate is typically low. The biases introduced because of this should be considered when interpreting the results from these studies.

One study, based on a survey sent to 1200 members of the American Society of Aesthetic Plastic Surgeons (4), asked physicians certified by the American Board of Plastic Surgery to report either knowing personally or knowing of one or more patients who had recently died deaths related to liposuction in their community. Duplication was avoided by collecting the initials of the decedent. There were 130 unique deaths reported that had occurred in any physician's practice and 95 of these deaths $(73 \%)$ occurred in the practices of board-certified plastic surgeons. With procedure estimates provided by the American Society of Plastic and Reconstructive Surgeons, the authors estimated the total number of lipoplasties performed between 1994 and 1998 by board-certified plastic surgeons to be 496,245 . Using this denominator, the death rate directly related to lipoplasty performed by board-certified plastic surgeons was 19.1/100,000 $(95 / 496,245)$ or one/5236 procedures. The most frequent cause of death was pulmonary thromboembolism $(23.1 \%)$, followed by abdominal or viscus perforations (14.6\%). The fatality rate calculated in this study is quite similar to the rate from an unpublished survey performed by the American 
TABLE 2

Selected surveys and studies estimating death rates due to liposuction

\begin{tabular}{|c|c|c|}
\hline $\begin{array}{l}\text { Deaths reported/ } \\
\text { number of procedures }\end{array}$ & $\begin{array}{l}\text { Estimated death rate/ } \\
100,000 \text { procedures }\end{array}$ & Brief description of study (reference) \\
\hline 2 deaths $/ 75,591$ procedures & $2.6 / 100,000$ & $\begin{array}{l}\text { Voluntary mailed survey of } 2695 \text { American and Canadian members of the } \\
\text { American Society of Plastic and Reconstructive Surgeons (50), with responses } \\
\text { from } 935 \text { members (34.7\%). This study had a low response rate by voluntary } \\
\text { respondents. }\end{array}$ \\
\hline $\begin{array}{l}11 \text { deaths } />100,000 \text { procedures } \\
\text { over a five-year period }\end{array}$ & $11 / 100,000$ & $\begin{array}{l}1987 \text { report by commission on Surgical Lipectomy of the American } \\
\text { Society of Plastic and Reconstructive Surgeons; unpublished report } \\
\text { cited by Rohrich (9). }\end{array}$ \\
\hline 95 deaths $/ 496,245$ procedures & $19.9 / 100,000$ & $\begin{array}{l}\text { Random survey of board-certified American Society of Aesthetic } \\
\text { Plastic Surgeons members (917 of } 1200 \text { [76.4\%] response rate) (4). } \\
\text { Ninety-five deaths reported for estimated 496,245 procedures from } \\
1994 \text { to mid-1998; cited by Grazer and de Jong (4). }\end{array}$ \\
\hline \multirow[t]{2}{*}{5 deaths/24,295 procedures } & $20.6 / 100,000$ & $\begin{array}{l}\text { Survey of } 529 \text { responding American Society for Plastic and Reconstructive } \\
\text { Surgeons members (no information given on how many received survey); } \\
\text { unpublished study cited by Rohrich and Beran (1), and Grazer and } \\
\text { de Jong (4). }\end{array}$ \\
\hline & $100 / 100,000$ & $\begin{array}{l}\text { Unpublished study from The Doctors Company, a malpractice insurance } \\
\text { carrier, cited by Daane and Rockwell (6), and Hanke and Coleman (22). }\end{array}$ \\
\hline
\end{tabular}

Society of Plastic and Reconstructive Surgeons. In this survey of plastic surgeons, 70 serious complications, including five deaths, were reported in 24,295 (20.6/100,000) lipoplasty procedures $(1,4,6)$. Others have opined that the death rate may be higher, up to $100 / 100,000$ procedures based on the likely under-reporting of these incidents and an unpublished study in California by a malpractice carrier insuring plastic surgeons (6). Earlier estimates of death rates have been much lower, which may be due to shortcomings in the study designs or to real increases in the death rate associated with this procedure over time. It is noted that most of the studies that examined fatality rates in liposuction have not been published (Table 2), and that prospective studies on complications related to lipoplasty are needed.

\section{REPORTING ADVERSE EVENTS TO THE FDA}

To date, the FDA has received two adverse event reports related to liposuction. This is despite FDA mandatory reporting requirements for device manufacturers, importers and user facilities (eg, hospitals and nursing homes), as well as voluntary reporting through MedWatch, the FDA's safety information and adverse event reporting program (45). Given the growing literature on this subject, liposuctionrelated adverse events are under-reported to the FDA. Adverse events may be reported to the FDA via the MedWatch program by telephone at 1-800-FDA-1088, by fax at 1-800-FDA-0178, via the MedWatch Web site at www.fda.gov/medwatch or by mail at MedWatch, HF-2, FDA, 5600 Fishers Lane, Rockville, Maryland 20852-9787, USA.

\section{DISCUSSION}

Liposuction is the most popular cosmetic procedure in the United States, and is used for both body sculpting and weight reduction. The potential risks associated with lipo- suction are neither trivial nor well quantified. Further studies are required to quantify these risks and to clarify the risk factors leading to potentially adverse outcomes.

Because liposuction is typically a cosmetic procedure, with psychological and other benefits not easily measured, it is difficult to calculate a risk-benefit ratio (46). Plastic surgeons, dermatologists and other practitioners of suction lipectomy do not agree on guidelines for the application of this procedure with respect to appropriate patient selection, satisfactory outcomes or acceptable techniques. Patients are left to judge conflicting information on safety when even the experts cannot agree. Some patient information on liposuction that we reviewed (47) places the burden on the patient to interview prospective physicians about their experience, training and board certification, without empirical documentation of how much experience is satisfactory or scientific evidence of the degree to which these factors contribute to patient safety.

Improved studies documenting the risks involved in liposuction are necessary, as is clear and explicit patient information, to genuinely inform prospective patients of the range of potential complications, scientifically established rates of complications and risk factors so that patients can make informed decisions.

ACKNOWLEDGEMENTS: The authors gratefully acknowledge the generous contributions of Dr Roxolana Horbowyj from the Office of Device Evaluation, Division of General, Restorative, and Neurological Devices at the FDA for her patient review of the manuscript and for providing in-depth information on the regulation of devices used in the performance of liposuction. The opinions or assertions presented herein are the private views of the authors and are not to be construed as conveying either an official endorsement or criticism by the United States Department of Health and Human Services, the Public Health Service, or the FDA. 


\section{REFERENCES}

1. Rohrich RJ, Beran SJ. Is liposuction safe? Plast Reconstr Surg 1999; 104:819-22.

2. Hoeyberghs JL. Cosmetic surgery. BMJ 1999;18:512-6.

3. American Society of Plastic Surgeons. 2000 Cosmetic Surgery Trends. <http://www.plasticsurgery.org/mediactr/stats-06.pdf> (Version current at March 20, 2002)

4. Grazer FM, de Jong RH. Fatal outomes from liposuction: Census survey of cosmetic surgeons. Plast Reconstr Surg 2000;105:436-46.

5. Rao RB, Ely SF, Hoffman RS. Deaths related to liposuction. N Engl J Med 1999;340:1471-5.

6. Daane SP, Rockwell WB. Analysis of methods for reporting severe and mortal lipoplasty complications. Aesthetic Plast Surg 1999;23:303-6.

7. Fournier PF, Otteni FM. Lipodissection in body sculpturing: the dry procedure. Plast Reconstr Surg 1983;72:598-609.

8. Drake LA, Ceilley RI, Cornelison RL, et al. Guidelines of care for liposuction. J Am Acad Dermatol 1991;24:489-94.

9. Rohrich RJ. Body contouring. Sel Read Plast Surg 1995;7:1-37.

10. Young VL, Schorr MW. Report from the conference on ultrasound-assisted liposuction safety and effects. Clin Plast Surg $1999 ; 26: 481-524$

11. Mourad PD, Crum LA. A review and examination of ultrasound for lipoplasty. Clin Plast Surg 1999;26:409-22.

12. Bernstein G. Instrumentation for liposuction. Dermatol Clin 1999; 17:735-49.

13. Thornton LK, Nahai F. Equipment and instrumentation for ultrasound-assisted lipoplasty. Clin Plast Surg 1999;26:299-304.

14. Monsein LH. Primer on Medical Device Regulation. <http://www.rsna.org/REG/research/regulatory/monsein1.html> (Version current at March 20, 2002)

15. Thomson Medical Economics. Physicians Desk Reference. <http://www.medec.com> (Version current at March 20, 2002)

16. Klein JA. Tumescent technique for regional anesthesia permits lidocaine doses of $35 \mathrm{mg} / \mathrm{kg}$ for liposuction. J Dermatol Surg Oncol 1990;16:248-63.

17. Burk RW 3rd, Guzman-Stein G, Vasconez LO. Lidocaine and epinephrine levels in tumescent technique liposuction. Plast Reconstr Surg 1996;97:1379-84.

18. Ostad A, Kageyama N, Moy RL. Tumescent anesthesia with a lidocaine dose of $55 \mathrm{mg} / \mathrm{kg}$ is safe for liposuction. Dermatol Surg 1996;22:921-7.

19. Rubin JP, Bierman C, Rosow CE, et al. The tumescent technique: the effect of high tissue pressure and dilute epinephrine on absorption of lidocaine. Plast Reconstr Surg 1999;103:990-6

20. Klein JA, Kassarjdian N. Lidocaine toxicity with tumescent liposuction. Dermatol Surg 1997;23:1169-74.

21. Klein JA. Tumescent liposuction. In: Dzubow LM, ed. Cosmetic Dermatologic Surgery. Philadelphia: Lippincott Raven, 1998:163-9.

22. Hanke CW, Coleman WP. Morbidity and mortality related to liposuction. Dermatol Clin 1999;17:899-902.

23. Cook WR Jr. Liposculpture of the abdomen, flanks, and back. In: Cosmetic Dermatologic Surgery. Philadelphia: Lippincott Raven, 1998:171-84.

24. Rubinstein EH. An anesthesiologist's perspective of lipoplasty. Clin Plast Surg 1999;26:423-9.

25. Christman KD. Death following suction lipectomy and abdominoplasty. Plast Reconstr Surg 1986;78:428.

26. Gorney M. Liability in suction-assisted lipoplasty: a different perspective. Clin Plast Surg 1999;26:441-5.

27. Abbes M, Burgeon Y. Fat embolism after dermolipectomy and liposuction. Plast Reconstr Surg 1989;84:546-7. (Lett)

28. Laub DR Jr, Laub DR. Fat embolism syndrome after liposuction: a case report and review of the literature. Ann Plast Surg 1990;25:48-52.

29. Ross RM, Johnston GW. Fat embolism after liposuction. Chest 1988;93:1294-5.

30. Scroggins C, Barson PK. Fat embolism syndrome in a case of abdominal lipectomy with liposuction. Md Med J 1999;48:116-8.

31. Alexander J, Takeda D, Sanders G, Goldberg H. Fatal necrotizing fasciitis following suction-assisted lipectomy. Ann Plast Surg 1988;20:563-5.

32. Barillo DJ, Cancio C, Kim SH, Shirani KZ, Goodwin CW. Fatal and near fatal complications of liposuction. South Med J 1998;91:487-92.

33. Umeda T, Ohara H, Hayashi O, Ueki M, Hata Y. Toxic shock syndrome after suction lipectomy. Plast Reconstr Surg 2000;106:204-7.

34. Rhee CA, Smith RJ, Jackson IT. Toxic shock syndrome associated with suction-assisted lipectomy. Aesthetic Plast Surg 1994;18:161-3.

35. Vermeulen C, Serra M, Roujeau J-C. Deaths related to liposuction. N Engl J Med 1999;341:1000-1. (Lett)

36. Torres J, Murillo J, Bofill L, et al. Rapidly growing mycobacterial infection following liposuciton and liposculpture - Caracas, Venezuela, 1996-1998. MMWR Morb Mortal Wkly Rep 1998;47:1065-7.

37. Talmor M, Hoffman LA, Lieberman M. Intestinal perforation after suction lipoplasty: a case report and review of the literature. Ann Plast Surg 1997;38:169-72.

38. Gingrass MK. Lipoplasty complications and their prevention. Clin Plast Surg 1999;26:341-54.

39. Topaz M. Long-term possible hazardous effects of ultrasonically assisted lipoplasty. Plast Reconstr Surg 1998;102:280-2.

40. Howard BK, Beran SJ, Kenkel JM, Krueger J, Rohrich RJ. The effects of ultrasonic energy on peripheral nerves: implications for ultrasound-assisted liposuction. Plast Reconstr Surg 1999;103:984-9.

41. Coleman WP 3rd, Hanke CW, Glogau RG. Does the specialty of the physician affect fatality rates in liposuction? A comparison of specialty specific data. Dermatol Surg 2000;26:612-5.

42. Lamberg L. Dermatologists debate sentinal node biopsy, safety of liposuction and antibiotic prophylaxis. JAMA 2000;283:2223-4.

43. Klein JA. Tumescent techniques for local anesthesia improves safety in large-volume liposuction. Plast Reconstr Surg 1993;92:1085-98.

44. Perry AW, Petti C, Rankin M. Lidocaine is not necessary in liposuction. Plast Reconstr Surg 1999;104:1900-2.

45. Department of Health and Human Services, Public Health Service, Food and Drug Administration. Who Must Report. Medical Device Reporting for Manufacturers.

<http://www.fda.gov/cdrh/manual/mdrman.html\#whomust> (Version current at March 7, 2002)

46. Emergency Care Research Institute. Liposuction and other cosmetic surgery. Health Care Risk Control Surg Anesth 1996;20:1-6.

47. Plastic Surgery Information Service. Surgical Procedures Liposuction. <http://www.plasticsurgery.org/surgery/lipo.htm> (Version current at March 7, 2002)

48. Beckenstein MS, Grotting JC. Ulstrasound-assisted lipectomy using the solid probe: a restrospective review of 100 consecutive cases. Plast Reconstr Surg 2000;105:2161-74.

49. Hanke CW, Bernstein G, Bullock S. Safety of tumescent liposuction in 15,336 patients. National survey results. Dermatol Surg 1995;21:459-62.

50. Teimourian B, Rogers WB 3rd. A national survey of complications associated with suction lipectomy: a comparative study. Plast Reconstr Surg 1989;84:628-31.

51. Gilliland MD, Commons GW, Halperin B. Safety issues in ultrasound-assisted large-volume lipoplasty. Clin Plast Surg 1999;26:317-35.

52. Dillerud E. Suction lipoplasty: a report on complications, undesired results, and patient satisfaction based on 3511 procedures. Plast Reconstr Surg 1991;88:239-46.

53. Pitman GH, Teimourian B. Suction lipectomy: complications and results by survey. Plast Reconstr Surg 1985;76:65-9.

54. Hecksteden K, Bücheler M, Bootz F. Acute hearing loss after liposuction. Plast Reconstr Surg 1999;104:1534-6.

55. Lombardi AS, Quirke TE, Rauscher G. Acute median nerve compression associated with tumescent fluid administration. Plast Reconstr Surg 1998;102:235-7.

56. Rose GE. Acute renal failure in association with cosmetic suction lipectomy. Postgrad Med J 1985;61:1083-5.

57. Ovrebo KK, Grong K, Vindenes H. Small intestinal perforation and peritonitis after abdominal suction lipoplasty. Ann Plast Surg 1997;38:642-4. 